\title{
From the ethology of animals to the human ecology*
}

\author{
Od etologii zwierząt do ekologii człowieka
}

\section{Zbigniew kepko}

Institute of Ecology and Bioethics, Cardinal Stefan Wyszyński University in Warsaw, Poland

ORCID: https://orcid.org/0000-0002-7013-6371•z.lepko@uksw.edu.pl

\begin{abstract}
The title "From the ethology of animals to human ecology" acknowledges both the theories of evolution developed in numerous scientific fields of science, and the academic achievements of Konrad Lorenz and his partners, the development of which are shown through the order of studies they published, from the scope of classical ethology and the row of humanities, to philosophy and human ecology. Lorenz conducted an ethological examination of human culture, thereby uncovering its biological bases, its dynamics, social pathologies and means for overcoming them. Thanks to this Lorenz gained an insight into the character of the crisis of contemporary civilization, described and diagnosed it, presented the causes and proposed a cure. Lorenz recommended mobilizing efforts to create an ecological ethos for those surviving on Earth. Today it isn't possible to predict the future of Homo sapiens on our planet, however, it is our duty to prepare for our struggle to survive. It is not only about survival but also about the preservation of the human way of life. This is a matter of biological and spiritual survival. Therefore, Lorenz's ethological humanism takes on the mantle of a new 'evolutionary humanism'.
\end{abstract}

Keywords: ethology, animals, human ecology, culture, humans

Streszczenie: Artykuł Od etologii zwierząt do ekologii człowieka dotyczy silnego wpływu darwinowskiej teorii ewolucji na kulturę europejską z przełomu XIX XXX w. W ślad za tym koncentruje uwagę na osiągnięciach badawczych Konrada Lorenza i jego współpracowników. Ich rozwój uwidaczniają kolejne opracowania z zakresu humanistycznej relewancji etologii klasycznej, aż po filozofię i ekologię człowieka. Lorenz przeprowadził badanie etologiczne kultury ludzkiej, odkrywając w ten sposób jej biologiczne podstawy, jej dynamikę, społeczne patologie i sposoby ich przezwyciężania. Dzięki temu rozpoznał antropologiczny charakter kryzysu współczesnej cywilizacji, opisał go i zdiagnozował, przedstawił jego przyczyny i zaproponował antidotum. Tym samym stworzył teoretyczne podstawy etosu ekologicznego przetrwania cywilizowanej ludzkości. Choć dziś nie da się przewidzieć przyszłości Homo sapiens na naszej planecie, to jednak mamy obowiązek przygotować się do walki o przetrwanie. Nie chodzi przy tym jedynie o przetrwanie biologiczne, ale o zachowanie ludzkiego stylu życia. Z tej racji etologiczny humanizm Lorenza należy uznaćza współzzesną odmianę "humanizmu ewolucyjnego".

Słowa kluczowe: etologia, zwierzęta, ekologia człowieka, kultura, człowiek

\section{Introduction}

Both historians of science and evolutionary biologists agree that the creator of modern ethology, that is the comparative science of living beings, is Konrad Lorenz. They also unanimously emphasise, that the creation of ethology was fostered by the fascination of Konrad Lorenz with both the Darwinian theory of evolution conditioned by natural selection and the richness of the behavioural diversity of the animal world. Lorenz initially confirmed, strengthened and developed the discovery of the homologous nature of the behaviour

- This article was originally published in Polish as Łepko, Zbigniew. 2013. "Od etologii zwierząt do ekologii człowieka." Studia Ecologiae et Bioethicae 11(3): 9-28. The translation of the article into English was financed by the Ministry of Science and Higher Education of the Republic of Poland as part of the activities promoting science - Decision No. 676/P-DUN/2019 of 2 April 2019. Translation made by GROY Translations. 
of living creatures, and then, with a group of first students and collaborators developed the ethological theory of instinct. Those achievements are the foundation of modern ethology. As a result, its research area and relevant research methods have been defined. As a result, ethology has a permanent place among many branches of evolutionary biology (Festetics 1984, 77-78; Eibl-Eibesfeldt 1980, 15).

Mainly thanks to the research and literary works of Konrad Lorenz, his students and collaborators, over the past few decades, ethology has achieved significance and publicity far beyond evolutionary biology. For this reason, today the philosophical relevance of ethology is rightly spoken and its inspiring influence on ontology, the theory of knowledge, anthropology and ethics is emphasised (Lorenz 1983c, 7-9; Fiut 1994; Łepko 2004, 221-238). It is equally legitimate, to speak of the ethological inspiration of works in the field of psychology, sociology and pedagogy (Lorenz 1983c, 7-9; Eibl-Eibesfeldt 1980, 11-14, 547-551). For the same reason, we should also talk about the ethological inspiration of human ecology, that is of creation realistic basis of the ecological ethos of human survival. The active and creative involvement of ethologists in this field was widely recognised in the 1970s and 1980s of the previous century, primarily in Austria, but also in other German-speaking countries. The most complete expression of this recognition was giving Lorenz a tithe of the "ecological conscience of the nation" (Lötsch 1984, 123-133).

\section{From the Darwinian theory of evolution to the evolutionary theory of the behaviour of living beings}

The emergence of modern ethology was made possible thanks to the adoption of the enthusiasts and researchers of the animal world a Darwinian cognitive perspective. Intensively propagated by Ernst Haeckel in Germany and Thomas Henry Huxley in England, the theory of evolution conditioned by natural selection quickly gained popularity, found many supporters and led to rapid changes in science (Winkler and Schweinkhardt 1982, 30-34). One of the first effects of that was the nineteenth-century zoopsychology. In principle, it focused on individual observations of animal behaviour, rather than on their systematic study and causal explanation, and found supporters among those observers of nature, for whom Darwin's discoveries provided a reason for simplified excuses of an obvious relationship between a man and the animal world and a preference for an anthropomorphic approach to animals (Koenig 1983, 74-75).

Although 19th-century zoopsychology did not directly contribute to the systematic study of the ways of animal behaviour, however, in the circles of those concerned, several questions arose, which over time took the form of problems initiating discussions and disputes about the genesis of consciousness, the essence of instinct, the stimulus-response relationship, etc. The discrepancies here, arose at the turn of the 19th and 20th century, in the confrontation between William Mc'Dougall's representational psychology and John Watson's representational behaviourist psychology. This confrontation eventually took a radical form and thus delayed the use of Darwin's achievements in the study of animal behaviour. Only the reference to the same research methods and cognitive questions, used since Darwin's discoveries by evolutionary biology, has revealed the existence between those antagonized psychological positions of a "nobody's field" in the field of the study of the behaviour of living beings. Ethologists have stepped into this field, considering it as a self-specific subject of research (Lorenz 1983e, 110-111; Lorenz 1984a, 17-28).

A new chapter in the development of the study of animal behaviour was marked by the work of two zoologists: Austrian duck researcher Oskar Heinroth and American pigeon researcher Charles Otis Whitman. The results of their work were confirmed and significantly expanded, by the data on instinctive behaviour of animals, by a prominent student of Whitman Wallace 
Craig (Oeser 1984, 27). They all referred to the achievements of Darwin, who in his work The Descent of Man, and Selection in Relation to Sex explicitly referred the theory of evolution conditioned by natural selection to the possibility of identifying the causes of certain ways of behaviour of living beings. Speaking of the instinctive foundation of animal and human behaviour, he argued, that "instincts, that in any way turn out to be more beneficial than others, are gradually strengthened under the influence of natural selection until they finally surpass all other, less beneficial urges. This is due to the fact, that individuals, in whom the most advantageous instincts have developed to the highest degree, become privileged in the struggle for existence and stay alive when others must perish" (Darwin 1929, 133). Darwin also referred to several examples of animal behaviour: the cooperative behaviour of bees, the conditioned by drive behaviour of birds, and the behaviour of hunting dogs. Although the examples cited by him were based only on fragmentary observations and on the anthropomorphic descriptions of animal life popularised by Alfred Edmund Brehm at the time, the subsequent course of events, leading to the emergence of ethology, confirmed the validity not only of his cognitive intuition but also of the detailed statements he made. For this reason, Darwin's work on the origin of a man, and especially the chapter entitled a comparison of the mental powers of a man with the mental powers of lower animals, is considered by science theorists to be the first step towards comparative research on the theory of evolution of living beings (Oeser 1984, 25).

Darwin's intuitions were fully developed after the independent discovery of the homologous nature of the behaviour of living creatures by Heintroth and Withman. It proved that the behaviour of living creatures is a characteristic distinguishing feature of a given biological species, and thus is subject to evolution to the extent, that the morphological characteristics of that species are subject to. This discovery validated the methodology of behaviour- al research, according to which, the same method of asking cognitive questions is fully applicable to the behaviour of living creatures, which has been used in all branches of biology since the discoveries of Darwin. Biology specifically asks about the phylogenetic origin of a given trait and answers this question by reconstructing the family tree of current living creatures by comparing their similarities and differences. Biology asks, what capacities favouring the survival and spread of a species enhanced the selective pressure that influenced the formation of a given feature of the species (Lorenz 1984a, 10). According to this view, the behaviour of living beings is treated as a function of a system which owes its existence and its particular form to the historical process of formation of the world, which encompasses phylogeny, ontogenesis and, in the case of a man, cultural history.

The rise of ethology was a scientifically validated response to behaviourism, popular at that time, which treated the behaviour of living beings solely as a result of individual learning. This strongly critical reference to behaviourism initially caused cognitive attention of ethologists to focus solely on the innate foundations of certain ways of behaving of living beings. This one-sided nature did not mean that the ecologists questioned the importance of acquired elements of the behavioural repertoire of living beings, but rather did not consider them to be an object of research specific to ethology. While more and more results of observations were obtained, on the behaviour of jackdaws, greylag geese and hunting dogs, that is animals that have great learning opportunities, the question of mutual relation of innate and acquired elements of the behavioural repertoire of living beings, became more and more explicit.

In the 1950s, this question was sharpened by criticism directed by American behaviourists against the ethological study of instinctive behaviour (Lehrman 1953, 337-363). Although initially, Lorenz did not see the substantive importance of their 
arguments in their criticism of behaviourists, due to their over - comprehension of reflexivity, the very fact of the criticism led him to transcend the framework of previous research. Maintaining his belief in heuristic importance of distinguishing what is innate from what is acquired in the behaviour of living beings, Lorenz gradually revised his theory regarding the manner and extent of their interrelationship. He summarised his work in several works (Lorenz 1984b; Lorenz 1965; Lorenz 1973). In each of them, he stressed, that an appropriate definition of behaviour, adequate to the actual state of affairs, must include, as a constitutive trait, its adaptability to certain environmental conditions. This means that information about the environment must somehow find its way to get into the living organism. This, in turn, can occur only via two paths: either during the evolution of species or during individual life of an organism. By accepting those findings, Lorenz defined the concept of what is innate as follows: "in the proper sense, innate, that is located in a genome, always means a program that contains all possible ways for the organism to develop, including what it can learn individually. This program contains information, on which the species-sustaining desirability of behaviour depends" (Lorenz 1983e, 112). From an ethological point of view, it is therefore correct to think, that innate behaviour is part of the learned one, that is, hierarchically organised ways of instinctive behaviour are the basis for the development of all learning mechanisms.

Developed in the 1930s and further developed in the following decades, the ethological theory of instinct, sort of, summarises the achievements of ethology from the first stage of its existence (Festetics 1984, 77). At the same time, this theory provided a cognitive perspective not only for the further development of ethology, or other behavioural sciences but also humanistic fields of human knowledge, of which various varieties of anthropology and cultural theory deserve special emphasis (Łepko 1991, 157-279).

\section{From the theory of instinct to the theory of the instinctive basis of culture}

Lorenz confirmed the thesis he propagated, about the overwhelming nature of evolution, with the reconstruction of the phylogenetic path of humanization, that is, the creation of a unique systemic whole, capable of conceptual thinking and syntactic speech. It shows that a person's outstanding cognitive abilities are the result of processes that determine the natural history of the world. In this cognitive perspective, Lorenz speaks of the instinctive foundations of the human spirit (culture) and maintains, that human spiritual life becomes a new kind of life, subject to laws of development analogous to those, that govern phylogenesis at the lower level of integration of the living world (Lorenz 1983b: 246-274).

Although biological evolution and cultural evolution develop at different levels of integration of the living world, however, each of them refers to a system, which "engages in a very active enterprise, aiming at obtaining at the same time energy capital and treasure of knowledge, while each time, having one of them promotes the acquisition of the other" (Lorenz 1977: 72). In analogy to the process of biological evolution one can thus talk about the unplanned and zigzagging course of cultural evolution, involving inheritance and variability and the creative factor of the game of diversity, that is, the game of everything with everything.

Referring to the instinctive foundations of human culture, ethologists from the Lorenz's school, do not negate its specific dynamics and mileage. Otherwise, they wouldn't talk, at all about the evolution of spirit and culture. The similarities shown between biological and cultural evolution do not exceed the level of analogy and actually serve to highlight the specificity of human culture. It includes several distinguishing features that allow identification of the causes of the formation and demise of cultures (Lorenz 1977, 291-376; Lorenz 1983a, 70-84). Thus, the rate of cultural evolution is shown to be much higher than the one of biological evolution, 
showing a constant tendency to grow. It is a function of a specific way of acquiring, collecting and communicating information. While the biological way of collecting information only leads to the genome, and the gains achieved during ontogenesis cannot be passed on to descendants, human cognitive abilities allow cultural transmission and widespread use of individually acquired experiences. Thus, while the inheritance of individually acquired properties does not occur during biological evolution, the cultural evolution is primarily based on such inheritance. During biological evolution, genetic information is acquired gradually and becomes phenotypic after many generations under one-way selection pressure. In the process of cultural evolution, each information acquired can be passed on to direct descendants. This mechanism causes a huge increase in human knowledge and an acceleration in the rate of development in all spheres of cultural life. Furthermore, the characteristic of cultural evolution draws attention to the fact, that biological evolution creates a variety of genetic programs, and thus, ultimately a variety of biological species. Cultural evolution, on the other hand, is only related to the biological species Homo sapiens and creates a variety of external structures towards it.

In addition to those fundamental differences between cultural development and phylogeny, ethologists mention several, even more subtle, peculiarities of cultural development (Lorenz 1977: 314). Convergent development occurs much more frequently in culture than in nature and inheriting of acquired properties allow the transmission of a set of traits of culture for other culture. Cultures can eventually mix, resulting in a fairly homogeneous whole, even if they have been developing independently of each other for a long time.

The thesis on the phylogenetic lineage of human spirit and culture does not equate with the thesis on the deterministic dependence of cultural evolution from biological evolution. In turn, it is consistent with the thesis, that "human genotype is essen- tial to culture, but it does not decide which one of many different modes of behaviour is currently being acquired. Similarly, human genes are indispensable while learning languages, but they do not specify in detail the currently mastered language" (Dobzansky et al. 1977, 451). This statement supports the view of ethologists, that the emergence of outstanding human cognition has initiated a unique feedback loop between culture and nature. "We have to accept," Lorenz writes, "that there are two kinds of processes involved in human development: a slow evolutionary process and many times faster cultural development" (Lorenz 1977, 296).

Thus, the feedback loop arrangement of culture and nature indicates the mutual dependence of its elements. The thesis on the biological determinants of culture should therefore be attached to the thesis on the cultural determinants of nature. Some examples of that, are provided by culturally transformed, that is ritualized, forms of biologically established ways of human behaviour. According to ethnologists from the school of Lorenz, culture is repressive towards human biology, and thus, it strives to create a kind of second nature in a man. A man is drawn into such a feedback loop between nature and culture. It is, therefore, necessary to define him taking into account the actual state of affairs. The definition of a man must therefore take into account the interaction of various factors that determine his condition. It must also take into account the relationships that take place between the layers of being, as well as the interaction between the biological and cultural determinants of everything that constitutes the human condition of a man. Omission of any of those factors means a theoretical adulteration of the image of a man and opens the way to practical destruction of manhood (Łepko 1991, 267-168).

\section{From the theory of culture to the theory of human survival in culture}

The recognition by ethologists of a man as a living being, who owes his powers and abilities to evolution, is a fundamental 
point of reflection on his possibilities and limitations in the environment of biological and spiritual life. According to this view, a man is completely and with everything, and thus to the most subtle layers of his being, connected to this environment. With the emergence of specifically human cognitive abilities, the biological relationship of a man with the world has been enriched by his sense of responsibility for the world (Lorenz 1983a, 281). Ethological theory of human responsibility for the world is presented within the framework of the theory of ecological survival of humanity (Łepko 2003, 158-170; Łepko 2002, 155-187).

In the past few decades, ecological permeability of ethologists has received recognition, pointing out the possibility of reversing the fatal course of things, caused by "habits of thinking fixed in the form of doctrines of the technocratic system" (Lorenz 1983a: 13). As a result, the ecological lectures of ethologists became important contributions to the study of the anthropological determinants of modern civilization. For, ethologists say things fundamentally important for an in-depth reflection on the "burning problems of modern times" (Eibl-Eibesfeldt 2000, 179).

Taking as a point of reference the concept of a man as a being of a cultural nature, ethologists consider the ecological crisis as one of the most pressing problems of modern times and see it as being caused by "deadly sins of civilized humanity", the chain of linked irreversible processes of biological and cultural destruction of the living space, as well as the condition of a man himself (Lorenz 1984a, 19-106). Thus, they emphasise the ethical and moral aspects of ecological matter. Even when Lorenz described the manifestations of the ecological crisis as "epidemiological diseases of human spirit" or "neurotic diseases of human culture", he did not deviate from the root concept of $\sin$ (Lorenz 1983d, 343-355). He was convinced of the need to consider environmental issues in conjunction with the moral responsibility of a man for the state of the environment. At the same time, he originally linked the category of sin with the diseases of a human spirit, actualised in various forms of culture. This allowed him to identify the ecological crisis as diagnosing diseases caused by sins and leading to both biological and spiritual death of humanity. It is therefore not surprising, that ethologists consider themselves to be doctors obliged to make a diagnosis consistent with the nature of the disease and the degree of its progression. They do so to counteract it effectively (Lorenz 1983: 11). The ethological approach to the ecological crisis is, therefore, not a purely theoretical concept, but contains clear practical references. It is not only about the description of the actual state of affairs, but also about the mobilisation of the intellectual and moral forces of a man in order to overcome the crisis phase of the functioning of the natural environment of human life.

The ethos of human survival postulated by ethologists is an expression of the human ability to set long-term goals. Let us recall, then, that the world of nonhuman nature uses highly risky behavioural strategies aimed at short-term success. Against this background, the uniqueness of a man is obvious. Wolfgang Wickler emphasises, that an important distinction between humans and living beings is the ability to predict far-reaching effects of their current actions in the natural environment (Wickler 1983, 139). This means that the ethos of human survival can be created with reference to talents inherent only in human nature. It also means that the ethical principle of human ecological responsibility of a man is a man himself.

Recognition in a man of the principle of responsibility for ecological safety of present and future generations of human beings determines The structure of working on the ethos of survival. The relevant proposals of ethologists indicate that two basic conditions must be met in this respect. Firstly, it is about the comprehensive, in this case ethological, knowledge of a man, and then shaping attitudes consistent with the theory of responsibility based on ethological knowledge of a man (Łepko 2003, 158-170). 
This structure of work on the ethos of survival of humanity translates into the structure of the ethos of survival itself. The proposal of ethologists contains a theoretical layer and a practical layer. The theoretical layer is made up of statements of ethologists that take into account the arguments of ecological anthropology referring to the concept of a man as a cultural being. The practical layer is made up of indications that take into account the active presence of a man in nature; it is, therefore, one of the varieties of practical philosophy that constitutes the search for the truth of human action in the world (Łepko 2001, 163).

Such a structure of the ethos of survival of humanity illustrates also expectations to convert the cognitive power of a man over nature to the power of a man over himself. In this context, Lorenz's anxiety is of particular importance, according to which "evil does not mean that that the study of nature has given us too much power over our external environment, but it means that, at least so far, it has given us too little power over ourselves" (Lorenz 1963, 143). This position of Lorenz is reinforced by other ethologists, who speak of the "insufficient sovereignty of a man towards himself" and the need for a man to develop a "self - reflective distance" towards himself (Eibl-Eibesfeldt 1991, 253).

Implementing the first condition of working on the ethos of human survivals searching for answers, characteristic for any anthropology, the question of an origin of a man, his current position in the world and his future. The evolutionary research perspective, adopted by ethology, makes it possible to use the results obtained from comparing the imaging devices of the world of various animals. Ethology recognises the validity of the results of the research on animal behaviour for the science of a man (Eibl-Eibesfeldt 1980, 26-27), and it even makes understanding a man dependent on understanding animals (Wuketits 1984a, 194). This relationship is obvious because the science of animal behaviour and the science of human behaviour are considered by ethologists to be on the same research plane. However, their attention in this respect does not focus on the relationship between a man and the world of animals, but on the specificity of a man (Weinberger 1983, 174-179).

The second condition for working on the ethos, and for the ethos of survival of humanity concerns human responsibility based on the truth about a man. Therefore, the ethological theory of the formation of responsible attitudes deserves particular attention. Ethology emphasises, that human capacity for responsibility naturally belongs to the biological species Homo sapiens. So it does not depend on any cultural tradition. Therefore, the sensations of values that generate responsibility do not have to be assimilated by a man by "hammering into his head, because they certainly awaken on their own, if the sense of perceiving figures in adolescents is given an unadulterated material of facts revealed to us by knowing the reality of nature" (Lorenz 1983a, 270).

The dependence of human responsibility for "something", indicated by ethologists, on perceived values of this "thing", leads to the conclusion that the processes that take place inside a man will decide about the future fate of humanity. It is about irrational feelings of value, rooted in nervous and sensory systems, a structure of which was formed through a phylogenetic process. The abilities to experience feelings are innate forms of possible experiencing the world and correspond to phylogenetically programmed norms of human behaviour. Based on them, a man can emotionally relate to phenomena in the environment and classify them as beautiful or ugly, good or bad, healthy or sick. Following the evaluative qualification, a man becomes aware of the responsibility for the environment (Lorenz 1983a, 85141). A consequence of ethological concept of a man is a specific concept of educating a man to be responsible for the environment. Thus, upbringing is not so much about making people aware, but about visualizing and directly experiencing the value of the natural environment. Its effectiveness depends on improving human predisposition during adolescence. 
Ethological theory of the formation of ecologically responsible behaviour assumes, that the best school here is direct contact with nature. Although nature exists beyond good and evil, and for its existence it needs neither a man nor its valuation, a man present in nature perceives and feels its value. This is because of the human ability to see how beautiful the world is and how precious life is in its diversity. According to Lorenz, the biological relationship of a man with nature and his valuable attitude towards it generates love in a man for all that is alive. Thus, love understood this way, "imposes on an omnipotent man responsibility for life on our planet" (Lorenz 1983a, 270). Here, perspectives of ecological civilization come, that is, the aspiration to make a man friendly towards the world and to make the world friendly towards a man. The principle of this civilization is, therefore, a man himself, capable of re-evaluating previously accepted values. This disposition of a man creates hope, that he will recognise current threats of biological and spiritual life in time and will be able to oppose them (Łepko 2001, 162).

Ecological civilization is both an expression of the established peace between a man and nature, as well as peace between a man and other people. Eibl-Eibesfeldt confirms the cause-and-effect dependence of peace between a man and other people and peace between a man and non-human nature. For he is convinced, that both types of peace are inextricably linked with each other, for without peace with nature it is impossible to have peace with people. At the same time, however, he stresses, that "making peace with nature will only be sealed, when we humans, make peace with ourselves" (Eibl-Eibesfeldt 1991, 248).

Showing the dependence of social peace from ecological peace, Eibl-Eibesfeldt firms it, by pointing out the fundamental importance of education to respect the phenomenon of life as such. Respect for life is the most complete expression of admiration for nature. It is born from the experience of something inimitable, unique on the scale of the universe (Eibl-Eibes- feldt 1988, 261). There is no doubt, however, that the attempts to search for life in the universe have ended unsuccessfully so far. Fife somewhere else might exist, but it will still remain an extremely rare phenomenon. For this reason, respect for life is both an experience and a fundamental condition for peace between a man and nature. Here, admiration for life is transformed (it should be transformed) into a commitment to responsibility for its maintenance. Only then, respect for human life becomes possible. Education to respect life as such leads to the humanization of interpersonal relations (Eibl-Eibesfeldt 1991, 251).

\section{Conclusions}

The study entitled "From the ethology of animals to the human ecology" shows not only the development of numerous fields of human cognition inspired by the Darwinian theory of evolution but also the development of scientific achievements of Konrad Lorenz and the researchers around him. This development is adequately illustrated by the sequence of studies published by Lorenz, both in the field of classical ethology and in some humanities, from philosophy to ecology of a man.

Such a broad spectrum of Lorenz's achievements proves right the methodological approach of ethologists, according to which, the analyses of animal behaviour determine an ever more complete understanding of a man. The research achievements of ethologists have made it possible to create a well-reasoned theory of biological determinants of sublime uniqueness of a man in the world of living beings, his civilizational threats and recommendations for his protection for the future. According to this view, a man is a cultural being, that is, "predisposed by nature and heritage in such a way that many of the structures of this predisposition require cultural tradition to be able to function, but on their part, they are the ones, that make tradition and culture possible at all" (Lorenz 1977, 296). This concept of a man opened Lorenz a possibility of ethological study of human culture, with particular at- 
tention to its instinctive bases, the dynamics of its functioning, its pathologies and, finally, recommendations to overcome them. Thanks to that, he recognised the nature of the crisis of modern civilization, described it, made a diagnosis, indicated its "pathogenic" causes and recommended appropriate treatment.

This line of interpretation concerning the crisis of modern civilization is maintained and enriched by argumentatively intellectual successors of K. Lorenz. They describe the location of civilized humanity, referring to the metaphor of a "dead-end", and recommend efforts to make it survive with regard to the specificity of species of Homo sapiens (Wuketits 2012). Thus, they uphold Lorenz's recommendations for the need to mobilise efforts to create an ethos of ecological survival of a man in a human way. Although in his view it is impossible to predict the future of Homo sapiens on our planet, he stresses the obligation to prepare for the struggle for survival (Lorenz 1983a: 11). In this case, it is about stopping and eliminating the mechanisms of technological civilization, that lead both to biological threats of our species and to the disappearance of all those qualities that constitute humanity. It, therefore, concerns biological and spiritual survival. The destruction of Homo sapiens means the destruction of both biological life and spiritual life on the Earth. In this situation, it's not just about surviving, it's about surviving humanly. This is where Lorenz's ethological humanism is expressed, which, according to the suggestions of experts in the field of his research and literary work, can be called "evolutionary humanism" (Wuketits 1984b, 187).

\section{Bibliography}

Darwin, Karol. 1929. O pochodzeniu człowieka. Warszawa: Biblioteka Dzieł Naukowych.

Dobzansky, Theodosuis, Francisco J. Ayala, Ledyard G. Stebbins, and James W. Valentine. 1977. Evolution. San Francisco: W. H. Freeman. Eibl-Eibesfeldt, Irenäus. 1980. Grundriss der vergleichenden Verhaltensforschung. Ethologie. München-Zürich: Piper \& Co. Verlag.
Eibl-Eibesfeldt, Irenäus. 1988. Galapagos. Arka Noego pośród Pacyfiku. Katowice: Wydawnictwo Śląsk.

Eibl-Eibesfeldt, Irenäus. 1991. Der Mensch das riskierte Wesen. Zur Naturgeschichte menschlicher Unvernunft. München: Piper \& Co. Verlag.

Eibl-Eibesfeldt, Irenäus. 2000. In der Falle des Kurzzeitdenkens, Mit 25 Abbildungen. München-Zürich: Piper \& Co. Verlag.

Festetics, Antal. 1984. „Das 'Du' zwischen Mensch und Tier." In Nichts ist schon dagewesen. Konrad Lorenz, seine Lehre i ihre Folgen, Hrsg. Franz Kreuzer, 69-98. MünchenZürich: Piper \& Co. Verlag.

Fiut, Ignacy S. 1994. Filozofia ewolucyjna Konrada Zachariasza Lorenza. Studium problemowe i historyczne. Kraków: Oficyna Wydawnicza Klubu Artystyczno-Literackiego.

Koenig, Otto. 1983. Verhaltensforschung in Österreich. Konrad Lorenz - 80 Jahre. Wien: Carl Ueberreuter Verlag.

Lehrman, Daniel S. 1953. "A critique of Konrad Lorenz's theory of instinctive behavior." Quarterly Review of Biology 28: 337-363.

Lorenz, Konrad. 1963. „Die Hoffnung auf Einsicht in das Wirken der Natur." In Die Hoffnungen unserer Zeit, Hrsg. Karl Jaspers, 143159. München: Piper.

Lorenz, Konrad. 1965. Evolution and Modification of Behaviour. Chicago: University of Chicago Press.

Lorenz, Konrad. 1973. Die Rückseite des Spiegels. Versuch einer Naturgeschichte menschlichen Erkennens. München: Piper \& Co. Verlag.

Lorenz, Konrad. 1977. Odwrotna strona zwierciadta. Próba historii naturalnej ludzkiego poznania. Warszawa: Państwowy Instytut Wydawniczy.

Lorenz, Konrad. 1983a. Der Abbau des Menschlichen. München-Zürich: Piper \& Co Verlag.

Lorenz, Konrad. 1983b. „Die instinktiven Grundlagen menschlicher Kultur." In Das Wirkungsgefüge der Natur und das Schicksal des Menschen, Hrsg. Konrad Lorenz, and Irenäus Eibl-Eibesfeldt, 246-274. MünchenZürich: Piper \& Co Verlag.

Lorenz, Konrad. 1983c. Vom Weltbild des Verhaltensforschers. München: Deutscher Taschenbuch Verlag. 
Lorenz, Konrad. 1983d. „Zivilisationspathologie und Kulturfreiheit." In Das Wirkungsgefüge der Natur und das Schicksal des Menschen, Hrsg. Konrad Lorenz, and Irenäus Eibl-Eibesfeldt, 343-355. München-Zürich: Piper \& Co Verlag.

Lorenz, Konrad. 1983e. „Evolution des Verhaltens." In Das Wirkungsgefüge der Natur und das Schicksal des Menschen, Hrsg. Konrad Lorenz, 110-136. München-Zürich: Piper \& Co Verlag.

Lorenz, Konrad. 1984a. Die acht Todsünden der zivilisierten Menschheit. München-Zürich: Piper \& Co Verlag.

Lorenz, Konrad. 1984b. „Phylogenetische Anpassung und adaptive Modifikation des Verhaltens." In Über tierisches und menschliches Verhalten. Aus dem Werdegang der Verhaltenslehre. Gesammelte Abhandlungen, Band 2, Hrsg. Konrad Lorenz, 301-358. MünchenZürich: Piper Verlag.

Lorenz, Konrad. 1984c. Vergleichende Verhaltensforschung. Grundlagen der Ethologie. München: Deutscher Taschenbuch Verlag.

Lötsch, Bernd. 1984. „Das ökologische Gewissen der Nation. Konrad Lorenz und die Umweltfrage." In Nichts ist schon dagewesen. Konrad Lorenz, seine Lehre i ihre Folgen, Hrsg. Franz Kreuzer, 123-133. München-Zürich: Piper \& Co. Verlag.

Łepko, Zbigniew. 1991. „Antropologia Konrada Lorenza. (Konrad Lorenz's Anthropology)." W $Z$ zagadnień filozofii przyrodoznawstwa $i$ filozofii przyrody, vol. XIII, red. Mieczysław Lubański, i Szczepan Ślaga, 267268. Warszawa: Wydawnictwo ATK.

Łepko, Zbigniew. 2001. „Etologiczne inspiracje ekofilozofii." W Ochrona środowiska spoteczno-przyrodniczego $w$ filozofii $i$ teologii, red. Józef M. Dołęga, Jacek W. Czartoszewski, i Antoni Skowroński, 135-164. Warszawa: Wydawnictwo UKSW.
Łepko, Zbigniew. 2002. „Etologiczna teoria kryzysu ekologicznego." W Od kosmologii do ekofilozofii. Problemy filozoficzne XXI wieku, red. Józef M. Dołęga, 155-187. Olecko: Wydawnictwo Wszechnicy Mazurskiej.

Łepko, Zbigniew. 2003. Antropologia kryzysu ekologicznego w świetle wspótczesnej literatury niemieckiej. Warszawa: Wydawnictwo UKSW.

Oeser, Erhard. 1984. „Zickzackweg auf dem der Wahrheit." In Nichts ist schon dagewesen. Konrad Lorenz, seine Lehre i ihre Folgen, Hrsg. Franz Kreuzer, 19-36. München-Zürich: Piper \& Co. Verlag.

Weinberger, Christiane. 1983. Evolution und Ethologie. Wissenschaftstheoretische Analysen. Mit einem Geleitwort von Konrad Lorenz. Wien-New York: Springer Verlag.

Wickler, Wolfgang. 1983. „Hat die Ehtik einen evolutionären Ursprung." In Die Verführung durch das Machbare. Ethische konflikte in der modernen Medizin und Biologie, Hrsg. Peter Koslowski, Philipp Kreuzer, and Reinhard Löw, 125-141. Stuttgart: S. Hirzel Verlag.

Winkler, Eike. 1982. Expedition Mensch. Streifzüge durch die Anthropologie. Mit einem Vorwort von Konrad Lorenz. Wien: Carl Ueberreuter Verlag.

Wuketits, Franz. 1984a. „Das geistige Leben eine neue art von Leben." In Nichts ist schon dagewesen. Konrad Lorenz, seine Lehre und ihre Folgen, Hrsg. Franz Kreuzer, 191-206. München-Zürich: Piper \& Co. Verlag.

Wuketits, Franz. 1984b. Evolution, Erkenntnis, Ethik. Folgerungen aus der modernen Biologie. Darmstadt: Wissenschaftliche Buchgesellschaft.

Wuketits, Franz. 2012. Zivilisation in der Sackgasse. Plädoyer für eine artgerechte Menschenhaltung. Murnau a. Staffelsee: MankauVerlag. 